\title{
Mededelingen
}

\section{Van het bestuur}

\section{Werkgroepen}

Vrijdag 15 mei zal de jaarlijkse bijeenkomst van vertegenwoordigers van de werkgroepen met het bestuur plaatsvinden. Dit jaar vindt deze ontmoeting plaats in het Erasmus MC te Rotterdam. Tijdens deze bijeenkomst geven de werkgroepen een overzicht van de activiteiten van het afgelopen studiejaar en worden de plannen voor het komende studiejaar bekendgemaakt.

\section{Overzicht werkgroepen van de NVMO}

De NVMO kent op dit moment de volgende werkgroepen:

- Communicatie Onderwijs (voorzitter mw. dr. E. van Weel-Baumgarten, UMC St Radboud).

- Medische vervolgopleidingen (voorzitter mw. dr. H. Mulder, UMC Utrecht).

- Diversiteit (voorzitter: dr. B. Bonke, Erasmus MC).
- Docentprofessionalisering (voorzitter: mw. prof. dr. W.M. Molenaar, UMC Groningen).

- E-learning (voorzitter: mw. drs. M. Dankbaar, Erasmus MC).

- Portfolio (voorzitter: mw. drs. H. Dekker, UMC Groningen).

- Praktijk van het Medisch Onderwijs (contactpersonen: drs. G.M. Verwijnen, Universiteit Maastricht en mw. drs. J.M.M. van de Ridder, UMC Utrecht). Een permanente voorzitter wordt thans gezocht.

- Professioneel gedrag (voorzitter: dr. S. van Luijk, VUmc).

- Simulatie- en gestandaardiseerde patiënten (coördinator: dr. J.-J. Rethans, Universiteit Maastricht).

- Skills- en simulatietechnieken (contactpersoon mw. dr. M. Schijven, UMC Utrecht).

- Wetenschappelijke Vorming (coördinatoren: mw. prof. dr. G. Croiset (UMCU), dr. T. de Goeij (MUMC) en dr. ing. H.W. Hooiveld, UMC Groningen). 